\section{QIJEI}

\author{
International \\ Journal for \\ Educational \\ Integrity
}

\title{
Curriculum redesign as a faculty-centred approach to plagiarism reduction
}

\author{
Sue Hrasky \\ University of Tasmania, Hobart, Australia \\ sue.hrasky@utas.edu.au \\ David Kronenberg \\ University of Tasmania, Hobart, Australia \\ david.kronenberg@utas.edu.au
}

Keywords: plagiarism, assessment, assessment strategies

\begin{abstract}
The incidence of plagiarism is increasing, exacerbated by the availability of many information sources via the internet. Traditional approaches for tackling plagiarism reflect two distinct philosophies: either educate the students or catch and punish inappropriate behaviour. Both philosophies assume that the responsibility for avoiding plagiarism is the student's so that whenever a problem is encountered, the blame rests with the student. The Australian Universities Teaching Committee (AUTC), established by the Australian Government in 2000, recommended a strategy reflecting a philosophy of sharing the responsibility for countering plagiarism across the student, staff and the institution. A key component of this approach relates to assessment design, which is the key focus of this paper. Practices regarding assessment and other strategies aimed at reducing the incidence of plagiarism at the University of Tasmania are documented and staff attitudes regarding the effectiveness of these strategies are identified. Impediments to implementing assessment strategies are also considered. By identifying both the strategies that staff see as effective, as well as the barriers to their implementation, universities can be forewarned about attitudes, obstacles, and associated resourcing implications that might be pertinent if the plagiarism response is to become a holistic one, in which all involved bear some responsibility.
\end{abstract}

\section{Introduction}

It is generally acknowledged that the incidence of plagiarism is increasing, a situation exacerbated by the ready availability of a variety of information sources via the internet (e.g. see Taylor, 2003; Stoney \& McMahon, 2004; Devlin, 2006). In fact Stoney and McMahon $(2004$, p. 2) describe plagiarism "as a battleground, where a war is waged between students and institutions, and played out using all of the means afforded by contemporary digital technologies". On the one hand, students turn to the web as a primary, familiar and convenient information source, the use of which might lead to intentional or unintentional plagiarism, while, on the other, institutions are increasing investment in digital detection capabilities, such as Turnitin software, as a defence.

Traditional approaches for tackling plagiarism reflect two distinct philosophies: the first seeks to educate the students by providing and reinforcing information about correct citation and referencing, acceptable collaboration and so on, while the second seeks to catch and punish behaviour deemed unacceptable (Taylor, 2003; Hart \& Freisner, 2004). Taylor (2003) and Macdonald and Carroll (2006) note that both approaches carry the implicit assumption that the responsibility for avoiding plagiarism is the

The International Journal for Educational Integrity is available online at:

http://www.ojs.unisa.edu.au/journals/index.php//JEI/

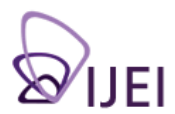


student's, and whenever a problem is encountered, the blame must therefore rest with the student rather than with faculty or the institution.

A problem with this is that the onus for compliance in both instances is placed squarely on the student, when it cannot be easily demonstrated that students either take the time to access the information available, or fully understand the purpose or outcomes of faculty academic policy, such as the use of programmes like Turnitin (McCarthy \& Rogerson, 2009). This can lead to accusations of misconduct, and resultant penalties that have long-lasting implications, within a process where actual intent to deceive is very difficult to establish (Yorke, Lawson, \& McMahon, 2009).

Commentators are now beginning to make calls for educators to consider pedagogy and assessment design as a key means of reducing the likelihood of plagiarism (e.g. Stoney \& McMahon, 2004; Hart \& Freisner, 2004; McGowan, 2005; Macdonald \& Carroll, 2006; N-Learning, 2009; Hughes, 2009).

Despite the growing interest in assessment design, Hughes (2009, p. 554) describes the literature on assessment task design and plagiarism minimisation as "surprisingly light". The purpose of this paper is to contribute to this area of the literature by focussing on attitudes and practices regarding assessment design and plagiarism. The specific aims of this study are:

- to document actual practices regarding assessment (and other) strategies in one university to assess the range and extent of existing responses;

- $\quad$ to identify which strategies faculty see as being more (or less) effective in reducing the likelihood of plagiarism; and

- $\quad$ to identify the key impediments to implementing assessment strategies.

This paper is set out to achieve these aims. It first considers broadly the different approaches taken to deal with plagiarism, particularly since 2000, with the establishment of the Australian Universities Teaching Committee (AUTC). This leads to the four critical research questions that form the thrust of the discussion, essentially the effectiveness and use (current and future) of educational strategies, of monitoring and detection strategies and of strategies aimed at curriculum redesign, together with a consideration of the impacts that perceived impediments have on the take up of a particular curriculum redesign strategy.

\section{Strategies to reduce plagiarism}

In 2000, the Australian Government established the AUTC with the brief to identify emerging issues in teaching and learning across Australian universities (ALTC 2009). In 2002, the Centre for Study of Higher Education (CSHE) for the AUTC completed and reported on the findings of a major project investigating the ideas and strategies that lead to quality in student assessment (James, Mclnnis, \& Devlin, 2002). One part of the report considered approaches to minimise plagiarism and recommended a four-part strategy comprising:

1. a collaborative effort at all levels from the individual staff member through to the institutional and policy level to counter plagiarism;

2. educating students appropriately;

3. implementing highly visible detection and monitoring procedures accompanied by appropriate punitive measures; and

4. designing assessment so that the possibility of plagiarism is minimised (after James, Mclnnis, \& Devlin, 2002, p. 37). 
The first arm of the strategy reflects a philosophy of sharing the responsibility for countering plagiarism across the student, the individual faculty member and the institution. Macdonald and Carroll (2006) argue that such a holistic approach is essential to countering the complex problem of plagiarism, a view echoed by Devlin (2006), Pickard (2006), Pittman-Munke and Berghoef (2008), and East (2009).

The second arm reflects the traditional 'educate' approach of providing information about appropriate behaviour, teaching necessary skills and communicating expectations as to what is acceptable and what is not. The Centre for the Study of Higher Education (2002) outlines 36 strategies to minimise plagiarism, of which six relate to educating students and communicating expectations. Items here include creating a culture of honesty, teaching skills of summarising, critical analysis, referencing and citation, and warning about theft of unprotected work.

The third arm of the AUTC/CSHE approach is reflective of the 'catch and punish' philosophy. It relates to detection and deterrents, and the visibility of efforts related to monitoring and punishment. Eight of the CSHE's (2002) minimisation strategies fall into this area, and include such items as: requiring electronic submission, researching electronic sources that students might find attractive, using coversheets, and enforcing deterrence penalties.

One concern regarding the use of the 'catch and punish' approach is that it is contextually overstated. In a single school, single Australian university research, Bretag and Green (2010) conclude that poor referencing skills represented the largest category of academic integrity cases dealt with, while blatant academic integrity breaches represented the smallest category. The appropriateness of a 'catch and punish' approach is questionable under these dynamics.

The final element of the four-part strategy relates to assessment design, encouraging assessment practices that reduce the likelihood of plagiarism and/or the opportunities for it to occur. The remainder of the CSHE's (2002) minimisation strategies relate to assessment. A review of the literature suggests that approaches can be categorised into three broad groups, reflecting the 'what', the 'how' and the 'when' of assessment. 'What' issues relate to both the question focus and to the specific aspects of the entire assignment process that are assessed. A very common and basic recommendation is to change the questions asked from year to year (Brown, 2001; Taylor, 2003; Alam, 2004; Hart \& Friesner, 2004). Further, these questions should set out clear expectations and require higher order thinking rather than mere data collection and descriptive reporting (Stefani \& Carroll, 2001; Olt, 2002; Taylor, 2003; Hart \& Friesner, 2004).

Many commentators suggest that there should be greater focus on the process that students go through to produce the final assessment piece rather than on the final piece itself (e.g. Olt, 2002; Born, 2003; Hart \& Friesner, 2004). This can be achieved by allocating marks for various stages of the process that need to be undertaken to complete the assessment task, requiring students to submit a log of their research process or evidence of various parts of it, such as first drafts, lists of sources identified and the process used to identify them, developed outlines, subsequent drafts and so on (Walker, 1998; Stefani \& Carroll, 2001; Olt, 2002; Zobel \& Hamilton, 2002; Born, 2003; Taylor, 2003; Alam, 2004; Darab, 2006; Hughes, 2009).

The 'how' of assessment encompasses possible modes that are less prone to plagiarism as they are less likely to be able to be purchased, copied or faked. Examples include creative poster presentations, mind maps, gaming, annotated bibliographies, and the use of technology through Weblogs, Wikis, electronic portfolios and the like (e.g. Carroll 2002; Bassendowski \& Salgado, 2005; Hughes, 2009). In-class contributions, activities and tests might be used more often to undertake assessment (Born, 2003, Alam, 2004). Where more traditional assessment tasks are retained, they can be supplemented with oral assessments (Stoney \& McMahon, 2004; Hughes, 2009). 
The 'when' relates to timing, although there is a lack of consensus regarding assessment frequency and plagiarism mitigation. For example, Born's (2003) suggestion that assessment tasks should be set more frequently is consistent with Olt (2002) who recommends that a series of smaller sequential tasks be used. The underlying logic is that it may be more difficult for students to persuade others to assist them, or to be able to afford to purchase assistance, when the number of tasks is large and where they are interdependent. Conversely, Alam (2004) recommends that the amount of assessment be reduced to avoid plagiarism activity that stems from time pressure and poor time management.

\section{The research questions}

This paper is concerned particularly with aspects of assessment design as a strategy to minimise plagiarism, within the context of the broader range of strategies that underpin a holistic approach to counteracting plagiarism. Reflecting the three operational arms of the four-part approach advocated by AUTC/CSHE (James, McInnis \& Devlin, 2002), (educate and communicate expectations, visibly monitor and penalise plagiarism, and assessment design), the first three research questions are:

RQ1: Which of a range of strategies aimed at educating students and making expectations clear are: used; considered effective; and are likely to be used in the future?

RQ2: Which of a range of strategies aimed at visibly monitoring, detecting and responding to incidences of plagiarism are: used; considered effective; and are likely to be used in the future?

RQ3: Which of a range of strategies aimed at designing assessment to minimise opportunities for plagiarism are: used; considered effective; and are likely to be used in the future?

A further research question addressed whether there is a relationship between the use of a strategy and possible impediments to its adoption:

RQ4: Is the degree of take up of particular assessment strategies linked to perceived impediments to curriculum redesign?

\section{Research method}

A questionnaire instrument was developed to be administered to academic teaching staff across the five faculties that make up the University of Tasmania (UTAS). It commenced with the definition of plagiarism that is made available on the University's website (University of Tasmania, 2010), namely:

the stealing or passing off as one's own (the idea or words of another); use (a created production) without crediting the source; to commit literary theft; present as new and original an idea or product derived from an existing source.

(Webster's Third New International Dictionary of the English Language, Unabridged, p. 1728)

This was followed by four sets of questions. In all cases throughout the questionnaire, where extent of agreement with a statement was sought, the following fully anchored scale was used:

$$
\begin{aligned}
& 1=\text { Strongly Disagree } \\
& 2=\text { Disagree }
\end{aligned}
$$




$$
\begin{aligned}
& 3=\text { Neutral } \\
& 4=\text { Agree } \\
& 5=\text { Strongly Agree }
\end{aligned}
$$

Sets one, two and three contained, respectively, plagiarism minimisation strategies that might be adopted either: to educate and communicate expectations; or to visibly monitor, detect and respond to plagiarism; or to design assessment tasks to minimise opportunities for plagiarism. These items were drawn from CSHE's (2002) list of strategies to minimise plagiarism, a link to which is provided on the UTAS webpage of staff resources regarding academic integrity. In each case, respondents were asked first whether or not they currently implemented the strategy, and secondly, they were asked to indicate the extent of their agreement as to whether the strategy would be both effective and likely to be used in the future.

Set four listed nine factors that might impede attempts to redesign assessment in order to minimise opportunities for plagiarism. These items drew on discussion by Devlin (2006), Stoney and McMahon (2004), Bretag (2005) and Hughes (2009), as well as on anecdotal observations of the researchers. Again, respondents were asked to indicate the extent to which they agreed that each was a barrier to assessment redesign. The final part of the questionnaire collected demographic data.

The questionnaire was pilot tested by three academic staff members from the Faculty of Business and minor ordering and wording refinements were made before mailing it in hard copy form to 774 academic staff members at UTAS. This number represented all staff identified as being in one of the six faculties at the University and who had teaching responsibilities as part of their role. Research institutes and research-only staff were not surveyed. The final instrument is available from the authors on request.

A one-sample t-test is used to assess significant differences between responses on the five-point scale used in the questionnaire. Kendall's tau correlation is used to assess associations between attitudes and strategies used as the data are treated as sets of paired observations from each individual respondent rather than pooled aggregate data. Kendall's tau is the appropriate measure of correlation in these circumstances.

\section{Results and discussion}

Two hundred and twenty-one usable responses were received, representing a response rate of $28.6 \%$. Table 1 presents the demographic data. Respondents typically were experienced academics, with $67 \%$ indicating that they had been employed in the tertiary sector for more than five years. Only $11 \%$ reported that they had less than two years of experience.

Table 1:

Academic level and discipline area of respondents

\begin{tabular}{|l|c|c|c|c|}
\hline \multicolumn{1}{|c|}{ Academic level } & $\begin{array}{c}\text { Proportion of } \\
\text { respondents }\end{array}$ & Faculty & $\begin{array}{c}\text { Proportion of } \\
\text { respondents }\end{array}$ & $\begin{array}{c}\text { Proportion of } \\
\text { University }\end{array}$ \\
\hline Professor & 5.6 & Arts & 19.8 & 21.3 \\
\hline Associate Professor & 9.8 & Business & 13.4 & 8.7 \\
\hline Senior Lecturer & 22.0 & Education & 11.5 & 8.7 \\
\hline Lecturer & 43.9 & Health Science & 25.3 & 28.1 \\
\hline Associate Lecturer & 15.4 & Law & 1.9 & 3.2 \\
\hline Other & 3.3 & $\begin{array}{c}\text { Science, Engineering } \\
\text { and Technology }\end{array}$ & 28.1 & 30.0 \\
\hline & 100.0 & & 100.0 & 100.0 \\
\hline
\end{tabular}


The first three research questions related to whether or not respondents used a particular strategy to reduce plagiarism and to their beliefs about effectiveness and use in the future. As reported in Table 2, all of the strategies associated with educating and communicating expectations about plagiarism were used. However, only three of the six strategies were more likely to be used than not used. These strategies were: creating a climate of involvement and interest rather than one of detection and punishment; teaching skills of critical analysis and building an argument; and teaching skills of referencing and citation. Respondents were significantly less likely than more likely to warn students of the possibility of their work being stolen or copied if left on university computers.

Similarly, as indicated in Table 3, all strategies aimed at visibly monitoring, detecting and responding to incidences of plagiarism were used. However, only two of the seven strategies were more likely than not to be used: supporting the use of deterrence penalties and the use of coversheets. In the context of UTAS, these are relatively easy strategies to implement at the individual faculty member level. It is a UTAS requirement that students use a standard-form signed coversheet, for which an electronic proforma is available, when submitting assignments. Similarly, deterrence penalties are the responsibility of the Head of School or a Disciplinary Committee, depending on the nature of the offence, and individual staff level involvement in determining penalties is minimal once the case of suspected plagiarism has been reported. Conversely, the two strategies that were significantly less likely to be used would require specific effort on the part of the individuals using them. These were: educate yourself about electronic options available and attractive to students in your discipline and use a search engine to help find the sites students are likely to find.

Table 2:

Strategies aimed at educating and communicating expectations

\begin{tabular}{|l|c|c|c|}
\hline \multicolumn{1}{|c|}{ Strategy } & $\begin{array}{c}\text { Per cent of } \\
\text { respondents } \\
\text { currently using }\end{array}$ & $\begin{array}{c}\text { Average } \\
\text { agreement score } \\
\text { on effectiveness } \\
(/ 5)\end{array}$ & $\begin{array}{c}\text { Average } \\
\text { agreement score } \\
\text { on future use } \\
(/ 5)\end{array}$ \\
\hline Teach the skills of referencing and citation & $84 \% \dagger$ & $4.36^{* *}$ & $4.31^{* *}$ \\
\hline $\begin{array}{l}\text { Teach skills of critical analysis and } \\
\text { building an argument }\end{array}$ & $77 \% \dagger$ & $4.30^{* *}$ & $4.12^{\star *}$ \\
\hline $\begin{array}{l}\text { Create a climate of involvement and } \\
\text { interest rather than one of detection and } \\
\text { punishment }\end{array}$ & $68 \% \dagger$ & $3.64^{*}$ & $3.76^{*}$ \\
\hline $\begin{array}{l}\text { Include mini-assignments that require } \\
\text { students to demonstrate skills in } \\
\text { summarising, paraphrasing, critical } \\
\text { analysis, argumentation, referencing and/ } \\
\text { or citation }\end{array}$ & $55 \%$ & $4.13^{* *}$ & $3.71^{*}$ \\
\hline $\begin{array}{l}\text { Teach the skills of summarising and } \\
\text { paraphrasing }\end{array}$ & $54 \%$ & $4.15^{* *}$ & $3.78^{*}$ \\
\hline $\begin{array}{l}\text { Warn students of the possibility of their } \\
\text { work/programs/files being stolen/copied if } \\
\text { left on the hard disks of university } \\
\text { computers }\end{array}$ & $26 \%+\dagger$ & $3.34^{*}$ & 3.22 \\
\hline
\end{tabular}

† significantly greater than $50 \%(p<0.05) \quad$ † significantly less than $50 \%(p<0.05)$ *significantly above the neutral point of $3(p<0.05){ }^{* *}$ significantly above the agree point of $4(p<0.05)$ 
Table 3:

Strategies aimed at visibly monitoring, detecting and responding to incidences of plagiarism

\begin{tabular}{|l|c|c|c|}
\hline \multicolumn{1}{|c|}{ Strategy } & $\begin{array}{c}\text { Per cent of } \\
\text { respondents } \\
\text { currently using }\end{array}$ & $\begin{array}{c}\text { Average } \\
\text { agreement score } \\
\text { on effectiveness } \\
(/ 5)\end{array}$ & $\begin{array}{c}\text { Average } \\
\text { agreement score } \\
\text { on future use } \\
(/ 5)\end{array}$ \\
\hline $\begin{array}{l}\text { Request that all work outside of } \\
\text { examinations be submitted with a cover } \\
\text { sheet defining plagiarism and requiring } \\
\text { the student's signature }\end{array}$ & $84 \% \dagger$ & $3.54^{*}$ & $4.09^{*}$ \\
\hline $\begin{array}{l}\text { Support the use of deterrence penalties } \\
\text { Demonstrate to your students your } \\
\text { awareness of electronic resources } \\
\text { available to them }\end{array}$ & $65 \% \dagger$ & $3.98^{*}$ & $3.91^{*}$ \\
\hline $\begin{array}{l}\text { Require all students to submit essays } \\
\text { and assignments electronically, while } \\
\text { making students aware of the plagiarism } \\
\text { checking software that exists }\end{array}$ & $48 \%$ & $3.71^{*}$ & $3.61^{*}$ \\
\hline $\begin{array}{l}\text { Publicise information about penalties } \\
\text { imposed when plagiarism is found }\end{array}$ & $44 \%$ & $3.96^{*}$ & $3.69^{*}$ \\
\hline $\begin{array}{l}\text { Use a search engine to help find the } \\
\text { sites students are likely to find }\end{array}$ & $36 \%+\dagger$ & $3.39^{*}$ & $3.22^{*}$ \\
\hline $\begin{array}{l}\text { Educate yourself about electronic options } \\
\text { available and attractive to students in } \\
\text { your discipline }\end{array}$ & $35 \%+\dagger$ & $3.52^{*}$ & $3.71^{*}$ \\
\hline
\end{tabular}

t significantly greater than $50 \%(p<0.05)$ t† significantly less than $50 \%(p<0.05)$

*significantly above the neutral point of $3(p<0.05)$

As reported in Table 4, of the nine strategies concerned with designing assessment to minimise opportunities for plagiarism, five were more likely than less likely to be used. These were:

- $\quad$ change the assessment tasks from year to year

- $\quad$ avoid assignments that ask students simply to collect, describe and present information

- $\quad$ use essay/assignment topics that integrate theory and examples or use personal experience

- $\quad$ assess work produced in class (oral or written)

- $\quad$ ask students to make an oral presentation as part of the assessment of written assignments.

Conversely, three strategies were less likely to be used, namely:

- $\quad$ require stages of the work to be submitted, such as first drafts, lists of sources identified and the process used to identify them and allocate marks for the various stages

- $\quad$ minimise the number of assessment tasks

- collect an annotated bibliography before the submission is due.

The strategy of requiring stages of the work to be submitted is of particular interest here, for whilst this strategy is deemed to be fairly effective, it is not widely used by the respondents (at $26 \%$ current use), nor is it a particularly strong contender for use 
in the future. Perhaps this is one strategy that suffers more than most from a perception (reasonable or not) of an unreasonably high workload attached.

The strategy of using alternatives to the standard essay, such as case studies, poster presentations, Wikis or Weblogs, was equally likely to be used as not used.

Table 4:

Strategies to design assessment to minimise opportunities for plagiarism

\begin{tabular}{|l|c|c|c|}
\hline \multicolumn{1}{|c|}{ Strategy } & $\begin{array}{c}\text { Per cent of } \\
\text { respondents } \\
\text { currently using }\end{array}$ & $\begin{array}{c}\text { Average } \\
\text { agreement score } \\
\text { on effectiveness } \\
(/ 5)\end{array}$ & $\begin{array}{c}\text { Average } \\
\text { agreement score } \\
\text { on future use } \\
\text { ( / 5) }\end{array}$ \\
\hline $\begin{array}{l}\text { Use essay/assignment topics that } \\
\text { integrate theory and examples or use } \\
\text { personal experience }\end{array}$ & $81 \%+$ & $4.21^{* *}$ & $4.18^{* *}$ \\
\hline $\begin{array}{l}\text { Avoid assignments that ask students } \\
\text { simply to collect, describe and present } \\
\text { information }\end{array}$ & $79 \%+$ & $4.05^{*}$ & $4.03^{*}$ \\
\hline $\begin{array}{l}\text { Change the assessment tasks from year } \\
\text { to year }\end{array}$ & $78 \%+$ & $4.22^{* *}$ & $4.16^{* *}$ \\
\hline $\begin{array}{l}\text { Assess work produced in class (oral or } \\
\text { written) }\end{array}$ & $60 \%+$ & $3.89^{*}$ & $3.73^{*}$ \\
\hline $\begin{array}{l}\text { Ask students to make an oral } \\
\text { presentation as part of the assessment of } \\
\text { written assignments }\end{array}$ & $59 \% \dagger$ & $3.93^{*}$ & $3.78^{*}$ \\
\hline $\begin{array}{l}\text { Use alternatives to the standard essay, } \\
\text { such as case studies, poster } \\
\text { presentations, Wikis or Weblogs }\end{array}$ & $54 \%$ & $3.65^{*}$ & $2.54^{* * *}$ \\
\hline $\begin{array}{l}\text { Minimise the number of assessment } \\
\text { tasks }\end{array}$ & $33 \%+\dagger$ & $2.81^{* * *}$ & $2.88^{*}$ \\
\hline $\begin{array}{l}\text { Require stages of the work to be } \\
\text { submitted, such as first drafts, lists of } \\
\text { sources identified and the process used } \\
\text { to identify them and allocate marks for } \\
\text { the various stages }\end{array}$ & $26 \%+$ & $3.40^{*}$ & 2.89 \\
\hline $\begin{array}{l}\text { Collect an annotated bibliography before } \\
\text { the submission is due }\end{array}$ & $10 \%+\dagger$ & & \\
\hline
\end{tabular}

† significantly greater than $50 \%(p<0.05) \quad$ †† significantly less than $50 \%(p<0.05)$

*significantly above the neutral point of $3(p<0.05){ }^{* *}$ significantly above the agree point of $4(p<0.05)$

${ }^{* * *}$ significantly below the neutral point of $3(p<0.05)$

The information in Table 2, Table 3 and Table 4 indicates that with the exception of two of the strategies related to assessment (Minimise the number of assessment tasks and Collect an annotated bibliography before the submission is due), respondents felt that all strategies would be effective in counteracting plagiarism, with each receiving an average score significantly above the neutral point of three on the five point scale. In terms of effectiveness, the top five ranked strategies across all three categories were:

1. Teach the skills of referencing and citation (4.36)

2. Teach skills of critical analysis and building an argument (4.30)

3. Change the assessment tasks from year to year (4.22)

4. Use essay/assignment topics that integrate theory and examples or use personal experience (4.21)

5. Teach skills of summarising and paraphrasing (4.15). 
Three items relate to education and communication and two to assessment, but there was no statistically significant difference in the scores assigned to these top five. Thus, a tentative conclusion that might be drawn from the data is that respondents consider educational and communication strategies and assessment design approaches as equally effective counter-plagiarism strategies and that any holistic approach should include elements of both.

Not surprisingly, in every case there was significant positive correlation between use of a strategy and perceptions about its effectiveness, as indicated by Kendall's tau (not individually reported). The correlation ranged between 0.16 and 0.41 for use and effectiveness of education and communication strategies, between 0.21 and 0.48 for visibility strategies and between 0.38 and 0.57 for assessment strategies. Thus, there appears to be strongest translation of potentially effective strategies into actual strategies in the case of assessment choices in that the more effective a strategy was felt to be, the more likely it also was that it was enacted, and vice versa.

The data on likely future use indicate that all but four of the strategies were likely to be implemented. Respondents were neutral about warning students in the future about the potential theft of unprotected work and also about requiring stages of assessed work to be submitted with marks allocated to stages undergone in completing the required piece of assessment. Respondents were significantly less likely to implement two of the assessment strategies in the future, namely, minimising the number of assessment tasks and collecting an annotated bibliography before submission date. While correlations between effectiveness and assessment strategies were strongest overall, fewer strategies from this set are likely to be implemented in the future. This might suggest that if a strategy is unlikely to be used in the future, this is most likely because it is deemed to be ineffective rather than because of any practical impediments to its utilisation.

As with the relationship between effectiveness and current use, there was consistent positive correlation between perceptions about effectiveness and likelihood that a strategy would be used in the future. The correlation ranged between 0.50 and 0.72 for future use and effectiveness of education and communication strategies, between 0.55 and 0.82 for visibility strategies and between 0.65 and 0.85 for assessment strategies. The magnitude of the correlation between effectiveness and future use for each strategy was consistently higher than that of the correlation between current use and effectiveness, and in the case of the educate and communicate and visibility strategies, it was around double. This might reflect two things: that some respondents may have been unaware of some of the strategies that might be implemented and/or for those whose effectiveness is known, there exists some impediment to their current use.

Table 5, Table 6 and Table 7 show the ranks for the three sets of strategies, respectively, on current use, effectiveness and likely future use. Whilst some ranks are relatively consistent, others are not, suggesting that implementation decisions might be driven by ease of use factors and barriers to implementation, rather than views on effectiveness.

Within the strategies aimed at educating and communicating expectations (Table 5), 'teach the skills of referencing and citation' is the first ranked strategy across current use, effectiveness and future use. Similarly 'teach skills of critical analysis and building an argument' holds a second ranking across the scale. Warning students of the possibility of theft is seen consistently as the least used, the least effective and the least likely to be used in the future. Across all items for educating and communicating expectations, there was a general consistency of ranking across the variables of use, effectiveness and possibility for future use. That is, strategies that are used are deemed to be both effective and usable in the future. On the other hand, strategies that are generally not used are seen as ineffective both now and in the future. 
For the strategies aimed at visibly monitoring, detecting and responding to incidences of plagiarism (Table 6), there is far less consistency. Request for the submission of a cover sheet is used extensively and will be used in the future, but this strategy is ranked fifth for effectiveness. The strategies that require all students to submit essays and assignments electronically and that support the use of deterrence penalties are ranked fourth and second respectively for current use, and ranked second and first respectively for effectiveness, yet score a lower ranking for future use. This implies that strategies that are currently utilised and deemed highly effective are not viewed strongly as strategies for future use. Alternatively, to publicise information about penalties imposed when plagiarism is found ranks equal fourth for current use, yet is seen as equal second ranking for effectiveness and for future use. 'Educate yourself about electronic options available and attractive to students in your discipline' is the lowest ranked for current use, seen as relatively ineffective, ranking sixth, yet maintains a fourth ranking for future use.

Table 5:

Ranking of strategies aimed at educating and communicating expectations

\begin{tabular}{|l|c|c|c|}
\hline \multicolumn{1}{|c|}{ Strategy } & $\begin{array}{c}\text { Rank on } \\
\text { use }\end{array}$ & $\begin{array}{c}\text { Rank on } \\
\text { effectiveness }\end{array}$ & $\begin{array}{c}\text { Rank on } \\
\text { future use }\end{array}$ \\
\hline Teach the skills of referencing and citation & 1 & 1 & 1 \\
\hline Teach skills of critical analysis and building an argument & 2 & 2 & 2 \\
\hline $\begin{array}{l}\text { Create a climate of involvement and interest rather than one } \\
\text { of detection and punishment }\end{array}$ & 3 & 5 & 4 \\
\hline $\begin{array}{l}\text { Include mini-assignments that require students to } \\
\text { demonstrate skills in summarising, paraphrasing, critical } \\
\text { analysis, argumentation, referencing and/or citation }\end{array}$ & 4 & 4 & 5 \\
\hline Teach the skills of summarising and paraphrasing & 5 & 3 & 3 \\
\hline $\begin{array}{l}\text { Warn students of the possibility of their work/programs/files } \\
\text { being stolen/copied if left on the hard disks of university } \\
\text { computers }\end{array}$ & 6 & 6 & 6 \\
\hline
\end{tabular}

In broad terms, Table 6 suggests that strategies seen as effective are not necessarily viewed as key strategies for future use. Perhaps ease of use factors and barriers to implementation are deemed to be more significant impediments here that out-muscle the perceived effectiveness in strategy implementation.

Table 6:

Ranking of strategies aimed at visibly monitoring, detecting and responding to incidences of plagiarism

\begin{tabular}{|l|c|c|c|}
\hline \multicolumn{1}{|c|}{ Strategy } & $\begin{array}{c}\text { Rank on } \\
\text { use }\end{array}$ & $\begin{array}{c}\text { Rank on } \\
\text { effectiveness }\end{array}$ & $\begin{array}{c}\text { Rank on } \\
\text { future use }\end{array}$ \\
\hline $\begin{array}{l}\text { Request that all work outside of examinations be submitted } \\
\text { with a cover sheet defining plagiarism and requiring the } \\
\text { student's signature }\end{array}$ & 1 & 5 & 1 \\
\hline $\begin{array}{l}\text { Support the use of deterrence penalties } \\
\text { Demonstrate to your students your awareness of electronic } \\
\text { resources available to them }\end{array}$ & 3 & 4 & 3 \\
\hline $\begin{array}{l}\text { Publicise information about penalties imposed when } \\
\text { plagiarism is found }\end{array}$ & $=4$ & $=2$ & 2 \\
\hline $\begin{array}{l}\text { Require all students to submit essays and assignments } \\
\text { electronically, while making students aware of the } \\
\text { plagiarism checking software that exists }\end{array}$ & $=4$ & $=2$ & 5 \\
\hline $\begin{array}{l}\text { Use a search engine to help find the sites students are } \\
\text { likely to find }\end{array}$ & 6 & 7 & 7 \\
\hline $\begin{array}{l}\text { Educate yourself about electronic options available and } \\
\text { attractive to students in your discipline }\end{array}$ & 7 & 6 & 4 \\
\hline
\end{tabular}


For strategies aimed to design assessment to minimise opportunities for plagiarism (Table 7) there is again a level of consistency similar to Table 5. Strategies that are currently used retain a similar ranking for effectiveness and for future use. The strategy to use essay/assignment topics that integrate theory and examples or use personal experience ranks first for current use, second for effectiveness and first for future use.

The third ranked strategy for current use, 'change the assessment tasks from year to year', is seen as the most effective strategy and supports that perception with a second ranking for future use. The lower ranked strategies for use are all deemed to be the least effective and the least likely to be utilised in the future.

Table 7:

Ranking of strategies to design assessment to minimise opportunities for plagiarism

\begin{tabular}{|l|c|c|c|}
\hline \multicolumn{1}{|c|}{ Strategy } & $\begin{array}{c}\text { Rank } \\
\text { on use }\end{array}$ & $\begin{array}{c}\text { Rank on } \\
\text { effectiveness }\end{array}$ & $\begin{array}{c}\text { Rank on } \\
\text { future use }\end{array}$ \\
\hline $\begin{array}{l}\text { Use essay/assignment topics that integrate theory and } \\
\text { examples or use personal experience }\end{array}$ & 1 & 2 & 1 \\
\hline $\begin{array}{l}\text { Avoid assignments that ask students simply to collect, } \\
\text { describe and present information }\end{array}$ & 2 & 3 & 3 \\
\hline Change the assessment tasks from year to year & 3 & 1 & 2 \\
\hline Assess work produced in class (oral or written) & 4 & 5 & 5 \\
\hline $\begin{array}{l}\text { Ask students to make an oral presentation as part of } \\
\text { the assessment of written assignments }\end{array}$ & 5 & 4 & 6 \\
\hline $\begin{array}{l}\text { Use alternatives to the standard essay, such as case } \\
\text { studies, poster presentations, Wikis or Weblogs }\end{array}$ & 6 & 6 & 8 \\
\hline Minimise the number of assessment tasks & 7 & 9 & 7 \\
\hline $\begin{array}{l}\text { Require stages of the work to be submitted, such as } \\
\text { first drafts, lists of sources identified and the process } \\
\text { used to identify them and allocate marks for the various } \\
\text { stages }\end{array}$ & 8 & 7 & 9 \\
\hline $\begin{array}{l}\text { Collect an annotated bibliography before the } \\
\text { submission is due }\end{array}$ & 9 & 8 & \\
\hline
\end{tabular}

The final research question asked whether the propensity to adopt a particular assessment strategy correlated with attitudes about potential factors that might impede attempts to redesign assessment to minimise opportunities for plagiarism.

Respondents' attitudes about impediments to action are documented in Table 8, ranked in order of the degree to which each is perceived to be an impediment. As the table shows, of the list provided, only three potential impediments ranked significantly above the neutral point. These were insufficient time, insufficient resources and support, and inadequate training.

Table 8:

Impediments to implementing plagiarism reduction strategies

\begin{tabular}{|l|c|}
\hline \multicolumn{1}{|c|}{ Impediment } & $\begin{array}{c}\text { Agreement score } \\
(/ 5)\end{array}$ \\
\hline Insufficient time & $3.98^{*}$ \\
\hline Insufficient resources and support & $3.58^{*}$ \\
\hline Inadequate training & $3.30^{*}$ \\
\hline Lack of interest from higher levels within the university & 3.04 \\
\hline SETL evaluations are likely to be negatively impacted & $2.71^{* *}$ \\
\hline Students will view the unit as less attractive & $2.62^{* *}$ \\
\hline External stakeholders expect traditional forms of assessment & $2.58^{*}$ \\
\hline The rigour of assessment will decline & $2.22^{*}$ \\
\hline The quality of learning outcomes will be diminished & $2.16^{* *}$ \\
\hline
\end{tabular}

*significantly above the neutral point of $3(p<0.05)$;

${ }^{* *}$ significantly below the neutral point of $3(p<0.05)$ 
Five items scored significantly below the neutral point suggesting that respondents disagreed that these were impediments. These items were:

- $\quad$ student Evaluation of Teaching and Learning (SETL) are likely to be negatively impacted

- $\quad$ students will view the unit as less attractive

- $\quad$ external stakeholders expect traditional forms of assessment

- $\quad$ the rigour of assessment will decline

- the quality of learning outcomes will be diminished.

In only three cases was there a significant negative correlation between a perceived impediment and use of an assessment strategy. In each case the impediment was insufficient time and this was negatively correlated with: asking students to make oral presentations; requiring stages of the work to be submitted; and avoiding assignments that ask students simply to collect, describe and present information. Avoiding the use of merely descriptive types of assignments was also significantly negatively correlated with concerns about insufficient resources and support.

However, as noted above, it may be the case that certain strategies are not being used because individuals were not aware of them. Therefore correlations were also calculated between the impediments rated as significant and whether the strategy would be used in the future. As well as reiterating the significant correlations noted above between current use and impediments, other significant negative associations emerge when future use is the focus. Requiring stages of work, such as drafts and lists of sources, to be submitted was negatively correlated with concerns about insufficient time and inefficient resources and support.

\section{Concluding comments}

This survey research provides a census of contemporary practice and perceptions in one university that provide insights on which both individuals and institutions might reflect to develop more proactive and holistic plagiarism strategies. The results suggest that respondents see strategies aimed both at educating and communicating expectations and with designing assessment tasks to minimise opportunities for plagiarism as important elements of plagiarism reduction attempts. This is consistent with calls for a more holistic approach to the management of plagiarism. The data further reveal that some of the strategies recommend by CSHE (2002) are less likely to be implemented, particularly those that are perceived to be relatively less effective. However, there is a supporting literature that suggests that all of the strategies ought to be effective. Thus, if the literature is correct, educative approaches may be necessary to raise awareness of the potential that such strategies offer.

Finally, a range of significant impediments to the implementation of assessmentdriven strategies to reduce plagiarism were identified, some of which appear to bear a direct relationship to the propensity to implement a particular strategy. Institutions might well benefit from resource-led strategies to focus on these impediments (insufficient time, resources and training), irrespective of whether they are perceived or real, in order to foster a holistic and proactive approach to implementing effective measure to reduce instances of plagiarism.

\section{References}

Alam, L. (2004). Is plagiarism more prevalent in some forms of assessment than others? In Beyond the comfort zone. Proceedings ASCILITE Perth 2004. http:// www.ascilite.org.au/conferences/perth04/procs/alam.html 
ALTC (2009). Australian Universities Teaching Committee 2000-2004. Retrieved January 27, 2010, from http://www.altc.edu.au/

Bassendowski, S., \& Salgado, A. (2005). Is plagiarism creating an opportunity for the development of new assessment strategies? International Journal of Nursing Education Scholarship, 2(1), 1-13. http://dx.doi.org/10.2202/1548-923X.1098

Born, A. (2003). How to reduce plagiarism. Journal of Information Systems Education, 14(3), 223-224. http://jise.org/Volume\%2014/14-3/Pdf/14(3)-223.pdf

Bretag, T. (2005). Implementing plagiarism policy in the internationalised university. Paper presented at the 2nd Asia-Pacific Educational Integrity Conference, University of Newcastle 2-3 December. http://www.newcastle.edu.au/ conference/apeic/papers_pdf/bretag_059_edd.pdf

Bretag, T., \& Green, M. (2010). 'Factors integral to the case': Categorising qualitative factors used to determine academic integrity outcomes. Paper presented at the 4th International Plagiarism Conference, Northumbria University 21-23 June. [abstract only] http://www.plagiarismadvice.org/documents/conference2010/ abstracts/4IPC_0010.pdf

Brown, J. (2001). Assessment: A guide for lecturers. LTSN Generic Centre Assessment Series 2001.

Carroll, J. (2002). A handbook for deterring plagiarism in higher education. Oxford: Oxford Centre for Staff and Learning Development, Oxford Brookes University.

Centre for the Study of Higher Education (CSHE) (2002). Minimising plagiarism. Retrieved January 11, 2010, from http://www.cshe.unimelb.edu.au/ assessinglearning/03/plagMain.html

Darab, S. (2006). A preventative approach to plagiarism: An empirical study of a firstyear unit for undergraduates. International Journal for Educational Integrity, 2 (2), 3-15.

Devlin, M. (2006). Policy, preparation and prevention: Proactive minimisation of student plagiarism. Journal of Higher Education Policy and Management, 28(1), $45-48$.

East, J. (2009). Aligning policy and practice: An approach to integrating academic integrity. Journal of Academic Language \& Learning, 3(1), 38-51.

Hart, M., \& Friesner, T. (2004). Plagiarism and poor academic practice - a threat to the extension of e-learning in higher education? Electronic Journal of ELearning, 2(2). Retrieved January 11, 2010, from http://www.ejel.org/volume-2/ vol2-issue1/issue1-art25.htm

Hughes, C. (2009). Assessment as text production: Drawing on systemic functional linguistics to frame the design and analysis of assessment tasks. Assessment \& Evaluation in Higher Education, 34(5), 553-563.

James, R., McInnis, C., \& Devlin, M. (2002). Assessing learning in Australian universities: Ideas, strategies and resources for quality in student assessment. Melbourne: Centre for Study for Higher Education and the Australian Universities Teaching Committee. http://www.cshe.unimelb.edu.au/ assessinglearning/docs/AssessingLearning.pdf

Macdonald, R., \& Carroll, J. (2006). Plagiarism - a complex issue requiring a holistic institutional approach. Assessment \& Evaluation in Higher Education, 31(2), 233-245.

McCarthy, G., \& Rogerson, A. M. (2009). Links are not enough: Using originality reports to improve academic standards, compliance and learning outcomes among postgraduate students. International Journal for Educational Integrity, 5 (2), 47-57.

McGowan, U. (2005). Plagiarism detection and prevention: Are we putting the cart before the horse? Proceedings HERDSA Melbourne 2005, 287-293. http:// conference.herdsa.org.au/2005/pdf/refereed/paper_412.pdf

N-Learning (2009). Plagiarism advice.org: Frequently asked questions. Retrieved January 11, 2010, from http://www.plagiarismadvice.org/documents/FAQ.pdf 
Olt, M. (2002). Ethics and distance education: Strategies for minimizing academic dishonesty in online assessment. Online Journal of Distance Learning Administration, 5(3). http://www.westga.edu/ distance/ojdla/fall53/olt53.html

Pickard, J. (2006). Staff and student attitudes to plagiarism at University College Northampton. Assessment \& Evaluation in Higher Education, 31(2), 215-232.

Pittman-Munke, P., \& Berghoef, M. (2008). Tackling plagiarism: Linking hi-tech, lowtech \& no-tech methods for detection. Journal of Social Work Values and Ethics, 5(1).

Stefani, L., \& Carroll, J. (2001). A briefing on plagiarism. LTSN Generic Centre Assessment Series 2001.

Stoney, S., \& McMahon, M. (2004). Bulletproof assessment, war stories, and tactics: Avoiding cybercheating. In Beyond the comfort zone. Proceedings ASCILITE Perth 2004. http://www.ascilite.org.au/conferences/perth04/procs/stoney.html

Taylor, G. (2003). The critical role of pedagogy in plagiarism prevention: The Unley ten point counter plagiarism strategy. Paper presented at the Academic Integrity: Plagiarism and other Perplexities Conference, Adelaide, November [verified 3 Sep 2011] http://studentweb.usq.edu.au/home/W0031814/assets/ Edn_Integ_paper.pdf

University of Tasmania (2010). A guide to academic integrity for students. Retrieved January 11, 2010 from http://www.academicintegrity.utas.edu.au/docs/ student_guide_to_academic_integrity.pdf

Walker, J. (1998). Student plagiarism in universities: What are we doing about it? Higher Education Research \& Development, 17(1), 89-106.

Yorke, J., Lawson, K., \& McMahon, G. (2009). Can we reliably determine intent in cases of plagiarism? International Journal for Educational Integrity, 5(2), 39-46.

Zobel, J., \& Hamilton, M. (2002). Managing student plagiarism in large academic departments. Australian Universities Review, 45(2), 23-30.

\section{About the authors}

Sue Hrasky is Associate Professor and Head of the School of Accounting and Corporate Governance at the University of Tasmania. Her research interests include accounting education issues, particularly those related to formative and summative assessment.

David Kronenberg has had an extensive and varied career in education in schools, and now uses that experience in teaching in the School of Accounting and Corporate Governance at UTAS. His work in both state and independent schools in Victoria, his teaching overseas, together with his educational program management and advisory work in Tasmania enhance his commitment to maximise the learning potential of all students. As Deputy Head and ACE State President he is hopeful of some impact on the quality of teaching at tertiary level.

An earlier version of this paper was originally published in the refereed proceedings of the $5^{\text {th }}$ Asia Pacific Conference on Educational Integrity: Culture and values. The University of Western Australia, 26-28 September: http://www.apcei.catl.uwa.edu.au/ procs 